\title{
What has Basel to do with Epworth? Karl Barth on Pietism and the theology of the Reformation
}

\section{David Gilland}

Dr DAVID ANDREw GILlAND is Lecturer in Systematic Theology at the Seminar für Evangelische Theologie und Religionspädagogik at the Technical University of Braunschweig, Germany. He is a John Wesley Fellow and a Fellow of The Center for Barth Studies at Princeton Theological Seminary.

d.gilland@tu-braunschweig.de Braunschweig, Germany

This article examines Karl Barth's earliest engagements with Pietism, rationalism and liberal Protestantism against the backdrop of the theologies of Albrecht Ritschl and Wilhelm Herrmann. The analysis then follows Barth through his rejection of liberal theology and his development of a dialectical theology over against Wilhelm Herrmann and with particular reference to Martin Luther's theologia crucis. The article concludes by examining Barth's comments on religious experience to a group of Methodist pastors in Switzerland in 1961.

KARL BARTH • DIALECTICAL THEOLOGY • PIETISM • RATIONALISM • LIBERAL PROTESTANTISM • METHODISM • ALBRECHT RITSCHL • WILLHELM HERRMANN • RELIGIOUS EXPERIENCE • CROSS 


\section{Introduction}

Karl Barth (1886-1968) and Methodism might at first appear to be an unusual topic, evoking clichés along the lines of 'What does Basel have to do with Epworth?' or similar. The reasons for this are legion. First, in what is generally understood to be Barth's sweeping rejection of the liberal theology of Friedrich Schleiermacher (1768-1834), Barth is also often understood to have done away altogether with religious experience, one of the central components of Methodist belief and practice. Further, Barth's earlier works, particularly his two famous commentaries on Paul's letter to the Romans, feature an explicit and an occasionally starkly polemical assessment of Pietism, ${ }^{1}$ in which the Methodist tradition, at least in part, has its roots. Later, as Barth's works became longer and increasingly doctrinal and he began to rely with increasing insistence on the theology of the Reformation and Post-Reformation Reformed orthodoxy, some of Barth's contemporaries saw him developing precisely the kind of dogmatism inherently problematic for Pietism. As a result, many from Pietist and Methodist circles, though certainly not all, have maintained a healthy skepticism of Barthian theology since its earliest days, if not rejecting it outright.

A closer look at Barth's life and earlier writings, however, betrays a much more complex relationship between Barth, liberal theology and Pietism, and thus with religious experience, than the rather stereotypical examples cited above. In order to move beyond these stereotypes, it will be necessary to resist treating theological liberalism, Pietism and Barth's earlier theology as if they were broad, generally uniform and diametrically opposed ideal categories and rather examine the particular theological statements each makes on the topics relevant to their interrelation and interaction. At the very least this will show us that we are dealing with theological perspectives that not only vary within and among themselves, but also share much in common with the perspectives to which they are reacting critically. Once we have unpacked Barth's complex interactions with Pietism and liberal Protestantism, we will be closer to understanding the tremendous contemporary engagement of scholars representing Methodism and the Holiness traditions with the theology of Karl Barth. 


\section{Barth's experience with liberalism and Pietism}

At the outset it is worth mentioning that Karl Barth was never a stranger to Pietist belief and practice. Not only were a number of his ancestors in Switzerland involved with Pietist groups, but Barth's father, Fritz, a professor of New Testament and Church History in Bern, was also generally sympathetic to a number of Pietist concerns such as 'a priority of life over doctrine', 'spiritual rebirth', sanctification and 'the coming kingdom of God'. ${ }^{2}$ While this did not make Fritz Barth a Pietist himself, his son Karl, who attended his lectures for a time at the beginning of his theological studies, would not have grown up either overly ignorant of or overly hostile to Pietism and its particular theological concerns. Later, as a student, when the young Barth would make his now famous first 'turn' towards the liberal theology of Friedrich Schleiermacher (1768-1834) - seemingly in part an act of rebellion towards his more conservative father - he would never adopt a theological agenda that was either wholeheartedly liberal ${ }^{3}$ or wholly hostile to Pietism, and was explicitly supportive of its experiential individualism in contrast to Protestant Orthodoxy. ${ }^{4}$ When Barth the pastor, now in his late 20 s and early 30 s, made his even more famous second 'turn' away from liberal theology towards the development of his own theological program, his writings at the time demonstrate a serious and continuous engagement with Pietist scholarship, biographies and other writings. ${ }^{5}$ As such, it would be impossible to tell the story of Barth's break with theological liberalism and his turn towards what we can call a 'theology of the Word of God', without also accounting for his engagements with Pietism at the same time.

Barth, however, for a time did become a dedicated follower of Schleiermacher earlier in his studies, and he eagerly went to hear the lectures of the famous liberal theologians of his day, particularly Adolf von Harnack (1851-1930) in Berlin and then Wilhelm Herrmann (1846-1922) in Marburg. Though all differing in their own ways, Harnack and Herrmann had both been variously influenced by Albrecht Ritschl (1822-89). ${ }^{6}$ After completing his significant three-volume historical, exegetical and constructive work on the doctrines of justification and reconciliation ${ }^{7}$ in the 1870 s, Ritschl took this information and now set his sights on continental Pietism. The result was a major three-volume historical and theological deconstruction of Pietism, ${ }^{8}$ for which Ritschl also published a separate introduction. Though often overlooked today, Ritschl's Prolegomena to the History of Pietism ${ }^{9}$ seeks to untangle the historical and theological lines from the Middle Ages through the Reformation and beyond 
to determine precisely how Pietism could have arisen in Protestantism. Ritschl argues that seventeenth-century Lutheran and Reformed Pietism was not a fulfillment of the original intention of the Reformers, but rather a remnant of medieval belief and practice ultimately grounded in monasticism. ${ }^{10}$ It survived the Reformation in the form of Anabaptism, and then reappeared in the Lutheran and Reformed churches as a 'reforming' tendency against the rationalism of the Protestant Orthodoxy, which for Ritschl was also a departure from the genuine Reformation. ${ }^{11}$ The theological crux of Ritschl's argument was that 'the material principle of the Reformation', that is, justification by faith, and its subsequent practical outworking on the Christian life, ${ }^{12}$ are not present in their authentic Reformation versions in Lutheran and Reformed Pietism. In sum, Ritschl not only argued that Pietism is at best a compromised form of Protestantism, he also cleared theological ground for his own constructive version of liberal Protestant theology as developed in his earlier work on justification and reconciliation.

Prior to his explicit rejection of liberal theology, Barth would have felt largely at home in this version of intellectual history with its twofold critique, first of rationalism ${ }^{13}$ and then of certain elements in Pietism, ${ }^{14}$ and its heralding of a third, generally more liberal and 'genuinely' Protestant option. But this certainly did not mean that the young Barth was opposed to everything that Pietism also valued. Thus, as a 'liberal' and with the Pietists, the student Barth shared in a critique of orthodoxy and dogmatic theology, especially of rationalism, metaphysics and natural theology, all forms of what is sometimes called 'speculative theology'. Medieval theologians such as Anselm of Canterbury, Thomas Aquinas, then Protestant Orthodoxy subsequent to the Reformation, as well as many of the Enlightenment era theologies such as that of Christian Wolff (1679-1754), and later Julius August Ludwig Wegscheider (1771-1849) and Christian Ernst Luthardt (1823-1902), to name a few, were all considered guilty in various ways of having subordinated Christian theology to human reason instead of, say, the Bible, revelation or an inner experience of Christ. ${ }^{15}$ Whereas considered individually these theologians have dramatically different intellectual programs, a rejection of the 'rationalism' and 'scholasticism' they have in common was understood by liberal theologians and Pietists alike as a genuinely Protestant theological emphasis. Ritschl, for example, understood his critique of rationalism and metaphysics to be a return to the authentic theology of Luther, in particular, a rejection of scholastic and speculative theology for a 'practical theology'. ${ }^{16}$ Further, this taming of reason was also compatible, in part, with the philosophical mood of the time, especially the 
work of Immanuel Kant, who places limits on speculation and orders legitimate religious knowledge to the realm of practical reason. Thus, the rejection of theological speculation was generally understood at the time as a commonality between the Reformation, Pietism and liberal Protestantism, and many of Barth's earliest writings demonstrate this thinking as well. ${ }^{17}$

Further, with liberalism and along with Pietism, the young Barth maintained a positive stance towards subjectivity and certain forms of individual religious experience. Indeed, liberal theological agendas from Schleiermacher onwards privileged religious experience and subjectivity in various forms. Whereas Schleiermacher had prioritized experience in terms of interiority - an immediate feeling of absolute dependence on God - Barth had fallen under the influence of Wilhelm Herrmann. Here, Christoph Chalamet's work is of particular importance in demonstrating that Herrmann was not your average liberal Protestant theologian, but is better understood as the first 'dialectical theologian' - a school whose most famous, albeit starkly different, representatives would be Karl Barth and Rudolf Bultmann (1884-1976). In Herrmann's works one finds a variety of expressions which we might anachronistically say sound very much like Barth, such as an emphasis on God's self-revelation to the believer and the believer's response in faith as trust. ${ }^{18} \mathrm{God}$ is also transcendent for Herrmann, meaning God's self-revelation, contra speculation, is neither accessible nor verifiable by reason. Further, faith is selfauthenticating and not subject to investigation by science (contra the historicism of Ernst Troeltsch), though Christianity as a religion and the Bible are. ${ }^{19}$ God's acts, therefore, are how we know God, and God encounters the believer in the believer's experience of 'the power of Jesus Christ's inner life.'20 Chalamet puts it in this way: 'Herrmann's theology is an actualist theology: it is concerned with God encountering us in an act (in actu) right now, in our present life, and not simply with a past event of history. ${ }^{21}$ As such, for Herrmann there can be no neutral or objective relationship with God in Christ - one, for example, that could be encompassed in a dogmatics - but God always changes those whom God encounters, and to be encountered by God means to be 'born again' and 'converted'.22 Thus, as a passionate disciple of Herrmann, it is clear that the young Barth shared an interest in individual religious experience with Pietism, though one that was very different from that of Schleiermacher or Albrecht Ritschl.

But, of course, Barth also had his concerns with certain expressions within Pietist thought and practice. Although he did not question the significance of religious experience as such, he did question how certain Pietists had 
understood it, along with tendencies towards moralism and an abiding focus on who is Christian and who not. ${ }^{23}$ Finally, in sharp distinction from some prominent Pietist theologians and aligned with liberalism, the young Barth would have explicitly rejected biblicism and also embraced higher biblical criticism.

\section{Barth on Pietism and the theology of the Reformation}

Whereas Barth always reckoned critically with liberal theology, even in his student days, it essentially fell apart for him as a viable theological option when he saw his beloved teachers give explicit public assent in writing to Germany's war policy in 1914. ${ }^{24}$ As a Swiss citizen, Barth experienced this event as an indictment not just of Schleiermacher's theology, but of the entire liberal apparatus, including the theology of his own teachers such as Harnack and Herrmann, and especially the theological foundations for their politics and ethics. Although Barth now came to see his former teachers as opponents, he nevertheless ultimately retained his critical stance towards rationalism and Pietism, though he now also came to subject the liberal theology of his earlier mentors to his newly developing theological critiques. This first came to expression in a number of public lectures ${ }^{25}$ and sermons, but especially in Barth's first Romans commentary from 1919, which was then heavily revised and extended for the 1921 second edition. With respect to our present topic, we can say that Barth's initial, polemical move was to equate the subjective elements in both Pietism and rationalism with the subjective element in liberal theology. That is, despite the differences among these three 'isms', Barth came to see all three as taking their starting point in modern anthropology in a way that he saw as being inimical to the theology of the Reformation. That is, Barth came to see modernity and modern thought as the common source of both experiential Pietism and the rationalistic Enlightenment. As he would write later in the 1930s: they are 'two forms which are equally close to the Reformation and equally distant from it.26

As noted above, however, many Pietists understood their movement to be a reaction against rationalism and a restoration of the original intention of the Reformation. By contrast, whereas liberal theologians such as Albrecht Ritschl and Adolf von Harnack generally saw Pietism as a particularly acute misunderstanding of and departure from the Reformation, they typically also rejected rationalism and speculative theology. Chalamet writes the following 
in describing Ritschl, though it could apply equally well to Harnack:'Dialectical or indirect thinking was rejected as something characteristic of "ecclesiastical Orthodoxy", of the Old Testament and of Catholicism.'27 From this standpoint, much Christian theology and especially scholastic theology, whether medieval or Post-Reformation Protestant Orthodoxy, wrongly attempts to harmonize statements about God that are paradoxical or incompatible, such as God's love and wrath, or God's mercy and justice. Such skepticism also extends to attempts to combine the conception of God in the New Testament with that of God in the Old Testament, which many liberal theologians saw as being strictly incompatible. ${ }^{28}$ Ritschl and Harnack saw instances of dialectic and paradox in the writings of Luther - for example in his discussion of law and gospel, or of God hidden and revealed - as remnants of the early Church's compromise with pagan philosophy and its blossoming into medieval scholasticism. As a result, theologians such as Ritschl and Harnack attempted to offer a more purified version of Luther and Protestant theology, a concept of the God of the gospel without any hiddenness and an account of the Christian life without the negative experience of law and Anfechtung. Thus, whereas many liberal theologians and Pietists may have generally agreed that Pietism and rationalism were opposites, in particular that Pietism was an anti-modern reaction to modernist rationalism, ${ }^{29}$ their assessment of the relationship between Pietism and the Reformation was dramatically different.

From his liberal teachers, Barth would have come to see Pietism as a misunderstanding of the Reformation, at least in part. From Herrmann, however, he would have also come to understand the theological significance of the Reformation in a radically different way from that of Ritschl and Harnack. Herrmann rather saw the dialectical and paradoxical elements of Luther's theology to constitute a significant part not just of an understanding of God, but also of the Christian life. ${ }^{30}$ Chalamet writes: 'When Herrmann used the dialectic of God hidden and revealed, he understood it as God's hiddenness in his revelation and not behind it (both possibilities are present in Luther).'31 Further, Herrmann not only emphasized a positive experience of God's gospel promise, but also a negative, preparatory experience of God's law, including the experience of tribulation or temptation (Anfechtung). ${ }^{32}$ What God's hiddenness in God's revelation and the believer's experience of Anfechtung add up to for Herrmann is the awareness of God's sheer transcendence and the fact that the believer is a sinner whose relationship to God is conditioned by both law and gospel. With regard to rationalism, this means that there can be no direct access to God via reason, because God is transcendent and humans are 
sinful. With respect to Pietism, this means that any Christian experience of God is utterly dependent on God's self-revelation to the believer in Jesus Christ. Once the believer had encountered Jesus Christ, however, Herrmann could speak intensely about individual Christian experience of Christ and the organic unity of life that resulted. ${ }^{33}$

Though he gained much from Herrmann, Barth's break with liberalism would ultimately bring about a further radicalizing of this dialectical understanding of the relationship of God and humanity, also meaning that his critique of Pietism and religious experience would become more decided and sharp. Herrmann had posited a dialectical relationship of law and gospel between God and humanity, where humans would first be driven to the gospel by the negative experience of the law, ${ }^{34}$ but were then ushered into the kingdom of God via their experience of the 'power and life' of Jesus. ${ }^{35}$ Once integrated into the kingdom of God, so to speak, the Christian faithful would live out their faith in the world, particularly through marriage, family, culture and the state. ${ }^{36}$

Barth, however, ultimately took this dialectic a step further by denying that God's grace followed on automatically from the negative experience of the law. ${ }^{37}$ Further, Herrmann had emphasized the organic unity of life with Jesus in the kingdom of God after conversion leading to a positive development of the kingdom of God, a point which Barth also largely maintained throughout his first Epistle to the Romans. ${ }^{38}$ In the second edition of Romans, however, Barth came to reject all such given continuity between God and humanity by means of 'death', a concept which he acquired from the Basel church historian Franz Overbeck. ${ }^{39}$ Many have interpreted these passages by Barth as being grotesque, if not altogether unchristian and as implying a denial of any positive Christian experience of God at all. Though Barth's expression here is indeed harsh, his intention was not to deny the possibility of Christian experience as such, but rather to emphasize that Christian experience, not only new birth and conversion, but also the subsequent Christian life, are utterly dependent on Christ's death at every moment: 'Only in the Cross of Christ can we comprehend the truth and meaning of His Resurrection. ${ }^{40}$ Whereas Herrmann had posited organic continuity between God and humanity after new birth and conversion, leading into the kingdom of God with all its political implications, Barth rather came to emphasize radical discontinuity between God and humanity in terms of the Cross of Christ. In this, Barth intentionally meant to unsettle any possible notion that God's relationship to humanity could somehow become a possession of humanity, a possession from which one could derive - undialectically, or in a straightforward manner - a Christian 
ethical and political program such as Herrmann's. In essence, Barth saw such a move to be a flat denial of Luther's theology of the Cross (theologia crucis) and a return to a pre-Reformation theology of glory (theologia gloria). ${ }^{41}$

Though coming after the so-called Romans period, Barth's 1927 lecture 'The Word in Theology from Schleiermacher to Ritschl' ${ }^{\prime 2}$ first argues for the similarity between the rationalism of a theologian like Julius August Ludwig Wegscheider (1771-1849) and the liberal program of Schleiermacher on the common point that'man is the measure of all things'.43 That is, both the liberal Schleiermacher and the rationalist Wegscheider, despite their differences, place humanity at the center of their theology. Barth then goes to examine what he calls 'an apparent - but only apparent - protest' 44 against the liberal theology of Schleiermacher in the form of a number of nineteenth-century reactions to liberalism. Among these groups, Barth includes 'the Awakening theologians', who generally understood themselves to be pushing for a renewal of the theology of the Reformation. Barth's comments on the Pietist theologian Friedrich August Gottreu Tholuck (1799-1877) are particularly instructive in this connection:

What use is all the terrifying talk of sin, at least for theology, if it is still true for Tholuck even in his sermons that all revolves around 'the ability to experience', the human capacity for experiencing; if the miracle and the dialectic of this theology is simply the miracle and the dialectic of the human heart - of the inspired, the enthusiastic, the awakened heart but, for flesh is still flesh, still the human heart? What use is the rediscovery of Anselm's doctrine of the atonement and of Luther's doctrine of justification if the result is advice to concern one's self more than ever with one's self, with man $?^{45}$

As with Herrmann, Barth also finds in Tholuck's work the 'dialectical' qualification on the relationship between God and humanity that sin poses. Nonetheless, Barth still interprets Tholuck as characterizing the believer's relationship to God as one of immanence because this relationship appears to be located exclusively within the human heart. For Barth, Tholuck's emphasis on inwardness obviates his intention to draw support from Anselm on atonement and Luther on justification, both of whose respective doctrines conceive of God as acting on the believer from the outside. As such, Barth questions the legitimacy of Protestant character of the Awakening theology with a general assessment about 'the Semi-Pelagianism which entered 
Protestant theology in the eighteenth century by the double open door of Rationalism and Pietism.46

In sum, it is clear that the religious individualism that Barth had previously seen as a positive element of both liberalism and Pietism, ${ }^{47}$ he now saw as theologically unsustainable:

\begin{abstract}
What happened in the distant past has now faded away as such, and is less significant. Extreme Pietists were the first to say it [i.e. the historical event of the Cross] was meaningless as such ... The real birth of Christ is in our hearts; his real and saving death is that which we see accomplished in ourselves, that which we have to accomplish ourselves; his real resurrection is his triumph of those who believe in him. ${ }^{48}$
\end{abstract}

But Barth understood this not only to be theologically problematic, but also politically dangerous in that it seeks to interiorize

\begin{abstract}
all those elements of Christianity which seem to represent an outwardness, a contrast. The sought-for goal is the appropriation of Christianity, which is regarded as complete when all that is not one's own as such is dissolved and made one's own. ${ }^{49}$
\end{abstract}

In sum, Barth feared that an exclusive emphasis on individual religious experience led to a dissolution between the real event of justification on the Cross and the reality of the justified Christian life, a dissolution which, especially after his experience in 1914, he believed carried potentially disastrous consequences for Christian ethics and politics.

\title{
Conclusion: what has Basel to do with Epworth?
}

Barth's contact with Methodism throughout his life was sporadic, but seemingly positive on the whole. He not only engaged with Methodists in his various ecumenical activities, he also took on a number of Methodist students from home and abroad. Barth often used the term 'Methodism' in a pejorative sense in his earlier works, as did other theologians such as Dietrich Bonhoeffer, who were sympathetic to Barth's theology. 50 In the later volumes of the Church Dogmatics, Barth frequently mentions Pietism and Methodism 'in the same breath', so to speak, as a description of a general tendency with 
which he was fascinated, but frequently disagreed. ${ }^{51}$ As such, whatever one might say on Barth and Methodism will have to be set within the framework of Barth's intricate perspective on Pietism.

Unsurprisingly, Barth did precisely this during a friendly and theologically rich conversation with a number of Methodist preachers held in Switzerland in 1961. As the conversation quickly turns to the topic of religious experience, it is astonishing to see how many of Barth's earlier concerns about Pietism and religious experience reappear explicitly, over forty years after Barth's Romans period.

Asked about his personal understanding of the experience of salvation, Barth responds:

The certainty here concerns something that lies completely and wholly outside of me, not within me. When I consider myself, what I feel, my little or bit theology, my experience - yes I have these, but what I am certain about [is not this experience]. I am not certain about my certainty; I do not believe in my own faith; rather, I believe that which God has done in Christ. ${ }^{52}$

Barth is careful, however, to demonstrate that he is not rejecting the believer's experience of salvation as such, but rather qualifying what he understands to be its proper location: 'With respect to what I can experience psychologically of salvation: naturally salvation is something we can experience. ${ }^{13}$ However, Barth goes on to say that it is necessary to distinguish between human mind, will and conscience with respect to this experience and the source of the actual event of the experience itself: 'What there is on the human side, I will rejoice that I am permitted to have this treasure in a jar of clay. But I do not want to confuse the treasure for the jar. ${ }^{54}$ Barth then continues, commenting wryly, 'I do not know whether what I have said here is "Methodist orthodoxy" or not', concluding his statement by returning to a theme already apparent in his first commentary on Romans, though now in a much more positive tone: 'I do not deny the salvation experience. I wouldn't think of doing that! The salvation experience is that which happened on Golgotha. In contrast, my own experience is only a vessel. ${ }^{\prime 55} \mathrm{It}$ is significant here that Barth is not pointing towards a particular doctrinal statement about Christ or justification, but rather to the event of the Cross itself. The language is milder than his earlier emphasis on death from the 1920s, but the theological content remains remarkably similar. 


\section{David Gilland}

Noticing the generally positive character of Barth's statement about the salvation experience, one of the pastors then followed up by asking:'There was a time when you were not disposed to speak in this positive way about the experience of salvation. Considered on a purely psychological level, what has changed for you to bring this about?' Barth's response, which is worth quoting at length, rehearses some of the key points in his development as detailed in this paper above:

I will give you an answer. I come [originally] out of the liberal theology stream, from Wilhelm Herrmann in Marburg and also from Adolf Harnack ... I heard no word as often as the word 'experience.' I absorbed all this, and for years I preached to my people in Safenwil about this 'experience.' And then I discovered that behind this theology stood the great Schleiermacher. Then through my reading I also met up with Pietism. I noticed that before Friedrich Schleiermacher there was also a Philip Jakob Spener and an August Hermann Francke (back then I had not concerned myself so much with John Wesley) ...

Then in the pulpit I had my breath taken away. I began to read the Bible more and so to look more attentively at what God has done. [And then it dawned on me: the] Bible does not [testify to] 'experience,' rather to the acts of God. And then as it happens in these matters, there has to be a 180-degree turn made, from pious humans to God himself, who has done everything in Christ that was needed to redeem the world. Then I began to write books. I read a great deal [for this task], including many Pietist biographies, and in this activity I said to myself: wait a minute, it does not work like that! Pietism and rationalism are brothers: they [both think in] humancentered [ways] ... Whenever I heard the word 'Pietism' or just had the inkling it was close by, I believed that I had to engage it strongly. So it happened that with the position I took against the experientiality of salvation, I gave offense to many good, pious people. $^{56}$

As he did frequently in such conversations near the end of his life, Barth goes on to qualify his remarks, both past and present, with, 'Now I have become somewhat older ... Now I do not have to turn so fiercely against this expression of faith', though 'I do not have to take back anything. At that time, it was right, and these things had to be said. ${ }^{57}$ 
In this it is clear that Barth felt the time was appropriate for a softening of rhetoric, but certainly without a substantive change in theological content from his earliest expressions as a radically dialectical theologian: the event and experience of salvation was the Cross and Resurrection of Christ and this is an event in which a believer can share and experience, but also never make his or her own, because it always implies a particular kind of relationship between God and humanity. As a result, as least as far as Barth is concerned, the answer to the question of what Basel might have to do with Epworth can really only be answered by those willing to say where they themselves stand in relation to the event of the Cross. Whereas the interest among contemporary Holiness and Methodist scholars in Barth's theology may not prove that they find Barth convincing on this point, they have clearly shown that they find it compelling.

\section{Notes}

1. A translation of the first edition, Karl Barth, Der Römerbrief: (Erste Fassung) 1919 (ed. Hermann Schmidt; GA 2.16; Zürich: Theologischer Verlag, 1985), has yet to be published. The second edition is widely available in English as Karl Barth, The Epistle to the Romans, trans. Edwyn C. Hoskyns, Oxford: Oxford University, 1933.

2. Eberhard Busch, Karl Barth and the Pietists: The Young Karl Barth's Critique of Pietism and its Response, trans. Daniel W. Bloesch, Downer's Grove, IL: InterVarsity Press, 2004, pp. 11-12.

3. Christophe Chalamet, Dialectical Theologians: Wilhelm Herrmann, Karl Barth and Rudolf Bultmann, Zurich: Theologischer Verlag, 2005, pp. 65-81: 'Anyone who believes the young Barth was a purebread liberal theologian, i.e. a critically and historically minded, anthropocentric and immanentist theologian, should carefully (re-)read his early works' (p. 65).

4. Busch, Karl Barth and the Pietists, pp. 13-17.

5. See, for example, Karl Barth, 'Gespräch mit Methodistenprediger (1961)', in Hinrich Stoevesandt (ed.), Karl Barth: Gespräche, vol. 1, 1959-1962, GA 4.1, Zurich: Theologischer Verlag, 1995, pp. 176-7. Karl Barth, 'Conversation with Methodist Pastors (1961)', trans. John Flett and David MacLachlan, in Karlfried Froehlich and Darrell Guder (eds), Barth in Conversation, vol. 1, 1959-1962, Louisville, KY: Westminster John Knox Press, forthcoming 2017. Busch, Karl Barth and the Pietists, pp. 1-130.

6. Busch, Karl Barth and the Pietists, pp. 33-59. On the relationship between Ritschl, Herrmann and Harnack, see Chalamet, Dialectical Theologians, pp. 45-52.

7. Albrecht Ritschl, Die christliche Lehre von der Rechtfertigung und Versöhnung, 3 vols, Bonn: Marcus, 1870-74. Only the third and most significant volume has been translated into English: The Christian Doctrine of Justification and Reconciliation: The Positive Development of the Doctrine, ed. H. R. Mackintosh and A. B. Macaulay, Edinburgh:T \& T Clark, 1902.

8. Albrecht Ritschl, Geschichte des Pietismus, 3 vols, Bonn: Marcus, 1880-86. 
9. Albrecht Ritschl, 'Prolegomena to the History of Pietism (1880)', in Three Essays, trans. Philip Hefner, Eugene, OR: Wipf, 1972.

10. Ritschl,'Prolegomena', pp. 56-105. For Ritschl, the issue is one of the meaning of Christian perfection. See, for example, p. 86: 'Catholic Christianity finds this governing image for its style of life [Lebensideal] in monasticism, in the bond created by the obligations of poverty, chastity and obedience (to the superior of the order).' Ritschl accordingly understandings all medieval piety to be an approximation to this idea, even the Franciscans, whose goal was to take the monastic ideal out into the world as opposed to the cloister. In contrast to the Catholic notion, Ritschl summarizes Augsburg Confession articles XVI and XXVII in this way: 'Perfection consists of fear and trust in God through all the conditions of life; this is more fully expressed as fear, trust in God's merciful providence, prayer, and the conscientious carrying out of one's vocation. Such a description is expressly intended as the antithesis to the catholic [sic!] view of monasticism.'

11. See Ritschl,'Prolegomena', pp. 122-139, as well as Albrecht Ritschl,'Theology and Metaphysics' (1881), in Three Essays, pp. 151-217. Ritschl sees Protestant Orthodoxy or Scholasticism to be not only a departure from genuine Protestantism and a return to medieval intellectualism, but also a capitulation to Platonism, with universal formal concepts, to which particular Christian content is then added. In 'Theology and Metaphysics', Ritschl argues that this method explicitly contradicts Luther's doctrine of God (pp. 162, 170, 203-212) and that the Christian's relationship with God is mediated by God's word in the form of either law or gospel, not a mystical union with Christ (unio mystica), which for Ritschl is not an authentically Lutheran doctrine, but rather an innovation of the seventeenth century (p. 198).

12. Cf. Ritschl, 'Prolegomena', pp. 84-86.

13. Busch, Karl Barth and the Pietists, p. 13.

14. Busch, Karl Barth and the Pietists, pp. 17-25.

15. This assessment is generally disputed today. On Anselm of Canterbury, see, for example, Karl Barth, Anselm: Fides Quarens Intellectum: Anselm's Proof for the Existence of God in the Context of his Theological System, Eugene, OR: Pickwick, 1960. On Aquinas, see Gilles Emery, La théologie trinitaire de saint Thomas d'Aquin, Paris: Cerf, 2004. On Protestant Orthodoxy, see, for example, Richard Muller, PostReformation Reformed Dogmatics, vol. 1: Prolegomena to Theology, Grand Rapids, MI: Baker, 1987. Wolff and Wegscheider, however, were unquestionably rationalistic in their orientation. With regard to his contemporary Luthardt, in 'Theology and Metaphysics' (1881), in Three Essays, pp. 153-154, Ritschl acknowledged he intended to prioritize revelation and faith over reason, but argued that his use of natural theology and dogmatism was simply inconsistent with his statements on the primacy of faith.

16. Ritschl,'Theology and Metaphysics', pp. 151-217, and Ritschl,'Prolegomena', pp. 122-139. Cf. Chalamet, Dialectical Theologians, p. 33.

17. Busch, Karl Barth and the Pietists, pp. 14-17.

18. Chalamet, Dialectical Theologians, p. 43.

19. Chalamet, Dialectical Theologians, p. 38-45. 
20. Chalamet, Dialectical Theologians, p 55. See, for example, the second part of Wilhelm Herrmann's, Ethik, in Hartmut Kreß (ed.), Wilhelm Herrmann: Ethik/Ernst Troeltsch: Grundprobleme der Ethik, Theologische Studien Texte, vol. 2, Woltrop: Hartmut Spenner, 2002, pp. 72-140, on 'New Birth' and 'Conversion'.

21. Chalamet, Dialectical Theologians, pp. 55-58 (p. 57).

22. Chalamet, Dialectical Theologians, p. 44.

23. See Busch, Karl Barth and the Pietists, pp. 17-25.

24. On this, see especially Eberhard Busch, Karl Barth: His Life from Letters and Autobiographical Texts, Grand Rapids, MI: Eerdmans, 1994, pp. 81-83.

25. See, for example, Karl Barth, The Word of God and Theology, trans. Amy Marga, London: T \& T Clark, 2001.

26. Karl Barth, Protestant Theology in the Nineteenth Century, trans. Brian Cozens and John Bowden, Grand Rapids, MI: Eerdmans, 2002, pp. $70 f .$, cf. p. 97.

27. Chalamet, Dialectical Theologians, pp. 45-52.

28. Notoriously, in his 1921 book Harnack came to herald the early Christian heretic Marcion as the one figure in the early Church who was able to overcome the inherent contradictions between law and gospel, primarily by rejecting the Old Testament and its God for the'new God' revealed in the New Testament. Cf. Adolf von Harnack, Marcion: Das Evangelium vom fremden Gott: Eine Monographie zur Geschichte der Grundlegung der katholischen Kirche, Darmstadt: Wiss. Buchges., 1996.

29. Cf. Busch, Karl Barth and the Pietists, pp. 22-23.

30. Chalamet, Dialectical Theologians, pp. 45-52.

31. Chalamet, Dialectical Theologians, p. 47. The comment in parentheses is also Chalamet's.

32. Chalamet, Dialectical Theologians, p. 51. For an example of Herrmann's understanding of law and gospel, see Herrmann, Ethik, pp. 72, 123.

33. Chalamet, Dialectical Theologians, pp. 54-58. Cf. Herrmann, Ethik, pp. 72-140

34. Herrmann, Ethik, pp. 28-37.

35. Herrmann, Ethik, pp. 76-77.

36. Herrmann, Ethik, pp. 140-87.

37. Cf. Chalamet, Dialectical Theologians, pp. 130-138.

38. See, for example, Barth, Der Römerbrief: (Erste Fassung) 1919, pp. 21, 172 and passim. Cf. Karl Barth and the Pietists, pp. 53-60.

39. See, for example, Barth, The Epistle to the Romans, p. 162. Cf. Busch, Karl Barth and the Pietists, pp. 73-78. Cf. Karl Barth, 'Unsettled Questions for Theology Today (1920)', in Theology and Church: Shorter Writings 1920-1928, trans. Louise Pettibone Smith, Eugene, OR: Wipf and Stock, 2015, pp. 55-73.

40. Barth, The Epistle to the Romans, p. 150.

41. Cf. Chalamet, Dialectical Theologians, pp. 134-138.

42. Karl Barth, 'The Word in Theology from Schleiermacher to Ritschl', in Theology and Church, pp. 200-216.

43. Barth, 'The Word in Theology from Schleiermacher to Ritschl', p. 203.

44. Barth, 'The Word in Theology from Schleiermacher to Ritschl', p. 205.

45. Barth, 'The Word in Theology from Schleiermacher to Ritschl', p. 206. 
46. Barth, 'The Word in Theology from Schleiermacher to Ritschl', p. 216.

47. Busch, Karl Barth and the Pietists, pp. 13-17.

48. Barth, Protestant Theology in the Nineteenth Century, p. 101. In Barth, Protestant Theology in the Nineteenth Century (pp. 119-120), Barth comments that the focus on the Cross of Christ in Pietism actually carried the Reformation notions of vicarious satisfaction and justification 'through pious and rational Pelagianism' of the time.

49. Barth, Protestant Theology in the Nineteenth Century, p. 100.

50. Barth, Der Römerbrief: (Erste Fassung) 1919, p. 279. This suspicion of 'Methodism' was also apparent, for example, in Dietrich Bonhoeffer, Letters and Papers from Prison: Enlarged Edition, ed. Eberhard Bethge, New York: Simon and Schuster, 1997, pp. 213, 327, 329, 340, 362, 374.

51. See, for example, Karl Barth, Church Dogmatics IV, 3.1: The Doctrine of Reconciliation, trans. G. W. Bromiley, London: T \& T Clark, 2004, pp. 28, 31, 38, 511, 513.

52. Barth, 'Gespräch mit Methodistenprediger', p. 175. This and the following translations have been taken from the forthcoming translation by John Flett and David MacLachlan, cited in note 5 above.

53. Barth, 'Gespräch mit Methodistenprediger', p. 175.

54. Barth, 'Gespräch mit Methodistenprediger', p. 175.

55. Barth, 'Gespräch mit Methodistenprediger', pp. 175-176.

56. Barth, 'Gespräch mit Methodistenprediger', pp. 176-177.

57. Barth, 'Gespräch mit Methodistenprediger', p. 177. 